\title{
Regional Cooperation on Shared Watercourses: The Policy and Legal Framework on Transboundary Water Resources in Mainland Tanzania
}

\author{
Kennedy Gastorn ${ }^{1}$
}

\begin{abstract}
Mainland Tanzania (Tanzania) is endowed with diverse water sources, some of which straddle national boundaries. ${ }^{2}$ Tanzania is located within two regional economic blocks, the Southern African Development Community (SADC) and the East African Community (EAC), and it also borders the eight countries of Kenya, Uganda, Rwanda, Burundi, Democratic Republic of Congo (DRC), Zambia, Malawi and Mozambique. The entire eastern part of Tanzania borders the Indian Ocean, which also houses the non-mainland territory of the United Republic of Tanzania, namely Zanzibar. All the neighbouring countries are state parties to SADC except Kenya, Uganda, Rwanda and Burundi who are partner states to the EAC.

This article discusses the existing policy and legal framework for the ownership, use, access, protection and management of transboundary water, which is defined as water resources contained within drainage or river basins which cross the geographical boundaries of and are shared with more than one sovereign country. ${ }^{3}$ It examines the existing national framework as well as the regional and international framework relevant to Tanzania. The need for proper regulation of transboundary waters has never been more imminent because water-quality degradation along with the structural and physical scarcity of global water supplies are culminating in a diverse array of transboundary water conflicts, particularly among the riparian states. ${ }^{4}$ Transboundary waters limit the discretion of nations under the international law principle of permanent sovereignty over natural resources, under which a state has absolute powers over natural wealth and resources within its territorial boundaries. ${ }^{5}$ Since all countries are generally hydrologically linked, it is necessary to negotiate and clarify the rights and obligations owed by a country regarding transboundary waters.
\end{abstract}

1 Associate Professor, University of Dar es Salaam School of Law. Email: kennedy@udsm.ac.tz.

2 Water is not a union matter as per First Schedule to the Constitution of the United Republic of Tanzania 1977. In terms of section 2 of the Water Resources Management Act 2009, the Act applies on the Mainland Tanzania only.

3 Section 3 of Water Resources Management Act 2009.

4 Mark Zeitoun and Jeroen Warner, Hydro-hegemony - a Framework for Analysis of Trans-boundary Water Conflicts, Water Policy 8 (2006), 435-460.

5 The General Assembly Resolution 1803 (XVII) on the Permanent Sovereignty over Natural Resources of 14 December 1962/ (GA Res. 1803 (XVII)/ 17 UN GAOR Supp. (No.17) at 15/ UN Doc. A/5217 (1962)). 


\section{Introduction}

Transboundary waters are understood, in Tanzania, to be water resources contained within drainage or river basins which cross geographical boundaries and are shared by more than one sovereign country. ${ }^{6}$ Water resources cover water courses, surface water, ground water and estuary water. Ground waters are waters that are naturally stored or which flow below the surface of the Earth and are not apparent in the surface waters, such as aquifers. Surface water, on the other hand, encompasses all water flowing over the surface of the Earth or which is contained in springs, natural lakes, reservoirs, or swamps, along with all water contained directly underneath river beds. ${ }^{7}$

It is a fact that competition among water users is increasing, especially in river basins that cross political boundaries, and will be a growing source of open conflicts until more stable and predictable water sharing and management policies are negotiated. At the moment, the focus of agreements on transboundary water has ceased to be confined to navigation rights and boundary demarcations, but rather tends to focus on the use, development, protection and conservation of water resources. ${ }^{8}$ As former UN Secretary-General Kofi Annan once said "fierce national competition over water resources has prompted fears that water issues contain the seeds of violent conflict. If all the world's peoples work together, a secure and sustainable water future can be ours." 9

Conflicts over shared water resources are diverse and may be traces as earlier as old as 3000 BC. They take various forms such as religious disputes, boundary disputes, development disputes as well political as one country may seek to possess or control another nation's water resources and thereby transforming water into an instrument of war. ${ }^{10}$ It is estimated that out of all water in the world $1.75 \%$ is locked in icecaps, $97.5 \%$ is saltwater and only $0.007 \%$ is freshwater economically available for human being ${ }^{11}$ out of which $10 \%$ of it is used is used for domestic purposes, $20 \%$ for industrial uses, and $70 \%$ for irrigated agriculture. ${ }^{12}$ At the same time population is growing while water largely remains finite or degrades. Water as a source of living has in many occasions also exacerbated the existing inter-states disputes. For instance, the dispute between India and Bangladesh started in 1960s

Also see Chris Armstrong, Against 'Permanent Sovereignty' Over Natural Resources, 2013, http://s srn.com/abstract $=2350884$ (accessed on 12 December 2014).

6 Section 3 of Water Resources Management Act 2009.

7 Section 3 of Water Resources Management Act 2009.

8 International Decade for Action, Water for Life, 2005-2015, http://www.un.org/waterforlifedecade /transboundary_waters.shtml (accessed on 12 December 2014).

9 International Decade for Action, note 7.

10 Peter Gleick, Water Conflict Chronology, http://www.oneonta.edu/faculty/allenth/WaterResources TracyAllen/Water\%20Conflict\%20Chronology.pdf, (accessed on 12 December 2014).

11 Aaron Wolf, Shared Waters: Conflict and Cooperation, Annual Review Environment Resources 32 (2007), 2.

12 OECD, Water and Violent Conflict, https://www.eda.admin.ch/content/dam/.../resource_en_92767 .pdf (accessed on 10 February 2015). 
when India constructed a barrage at Farakka which diverted a portion of the Ganges river flow away from its course into Bangladesh and thereby degraded surface and groundwater. Also the 1987, Palestinian Gaza Strip uprising in the West Bank against Israel was exacerbated by the steady deterioration of water quality. ${ }^{13}$

Peter Gleick has documented a comprehensive chronology of water conflicts including the 1975 conflict between South Africa and Angola when the former moved troops into Angola to occupy and defend the Ruacana hydropower complex, including the Gové Dam on the Kunene River in order to control the water resources of southwestern Africa and Namibia; the 1986 conflict between south Africa and Lesotho which led to an agreement between the two for water from the Highlands of Lesotho; the 1990s dispute between South Africa and Mozambique over Incomati River where dams constructed by the South African on the Incomati River basin reduced freshwater flows and increased salt levels in Mozambique's Incomati estuary; the 1990 disputes between Iraq, Syria and Turkey over the flow of the Euphrates river following the construction of Ataturk Dam by Turkey which restricted water flow to Syria, then supporting Kurdish rebels operating in southern Turkey; the 1992 dispute between Czechoslovakia and Hungary when the latter abrogated a 1977 treaty with Czechoslovakia about construction of the Gabcikovo/Nagymaros dam project based on environmental concerns. Slovakia constructed unilaterally the dam and diverted the Danube water flow into a canal inside the Slovakian republic; the 1994 Okavango River basin dispute between Botswana and upstream Namibia which resulted into an agreement to share resources of Okavango River through the Okavango River Basin Water Commission; ${ }^{14}$ the 1995 dispute between Ecuador and Peru over the control of the headwaters of Cenepa River which also became a border issue; and the 1997 dispute between Singapore and Malaysia where the latter threatened to cut supply of water to the former in retribution for criticisms by Singapore of policy in Malaysia. Nearly half of Singapore's water comes from Malaysia. ${ }^{15}$

\section{Water Sector in Tanzania}

The water sector in Tanzania is governed by the National Water Policy 2002, the Water Resources Management Act No.11 of 2009, and the Water Supply and Sanitation Act No. 12 of 2009. ${ }^{16}$ Since water is a multi-sectoral resource, there are other relevant laws that govern various aspects of water. This includes the Land Act 1999, which, inter alia, declared that any land parcel within a natural drainage system from which the water resource of the

13 Wolf, note 10, 14-25.

14 Wolf, note 10, 14-15.

15 Gleick, note 9, 33.

16 The Acts became operational on 1 August 2009 through the Government Notice No. 235 of 10 July 2009. 
drainage basin originates is reserved land $;^{17}$ the Forest Act 2002, which protects, inter alia, the ecosystem stability through conservation of forest biodiversity, water catchments, and water sheds; ${ }^{18}$ and the Environment Management Act 2004 which is comprehensive legislation dealing with the prevention of environmental degradation, including water. As will be seen below, most customary environmental international law principles are applicable to the management of shared water resources. ${ }^{19}$ For instance, section 4(3) of the Environment Management Act 2004 states that any person, court, or tribunal, acting in their capacity under state authority, shall be guided by the principle of international cooperation in their management of environmental resources which are shared by two or more states, as well as other principles of environmental preservation and sustainable development such as the precautionary principle, the polluter pays principle, the principle of eco-system integrity, the principle of public participation in the development policies, plans and processes for the management of the environment, the principle of access to justice, the principle of intergenerational equity and intra-generational equity and the principle of common but differentiated responsibilities. The Act makes it an offence to export any waste materials without a clear written permit issued by a competent authority of the receiving country. ${ }^{20}$

At the regional and international level, Tanzania is a member of the United Nations Charter of 1945 which recognizes the principle of permanent sovereignty over natural resources found within national boundaries. Tanzania abstained from voting for enactment of the United Nations Convention on the Law of the Non-Navigational Uses of International Watercourses of 1997 which is the only global treaty governing shared freshwater resources. Regionally, Tanzania has signed various multilateral water basin arrangements with neighbouring countries and is also a state party to the SADC and EAC.

Accordingly, this article discusses the existing policies and legal frameworks regarding transboundary water in Tanzania starting with the National Water Policy 2002, Water Resources Management Act 2009, the EAC Framework (mainly the Treaty for Establishment of the East African Community 1999), the SADC Framework (mainly the Revised Protocol of Shared Watercourses in the SADC 2000) and the UN Convention on the Law of the Non-Navigational Uses of International Watercourses of 1997, which was enacted in August 2014.

Tanzania has collaborative shared water arrangements with 17 countries and several international organisations. ${ }^{21}$ This includes the Nile Basin Initiative, which was entered into

17 Section 6(1)(b) Land Act 1999.

18 Section 22 of the Forest Act No. 14 of 2002.

19 Owen McIntyre, The Role of Customary Rules and Principles of International Environmental Law in the Protection of Shared International Freshwater Resources, Natural Resources Journal 46 (2006), 161.

20 Section 133(2) of the Environment Management Act 2004.

21 Jamhuri ya Muungano wa Tanzania, Taarifa ya Sekta ya Maji Katika Maadhimisho ya Miaka 50 ya Uhuru wa Tanzania Bara 1961-2011, 2011, 40. Also see Wizara ya Maji, Jamhuri ya Muungano wa Tanzania, Hotuba ya Waziri wa Maji Mhe. Prof. Jumanne Abdallah Maghembe 
with 9 other riparian states bordering the river Nile, the Congo River Basin, and the Zambezi River Basin. Seven national water basins associated with transboundary waters are: Lake Victoria Basin, Ruvuma River Basin, Central Water Basin, Pangani River Basin, Lake Nyasa Basin, Lake Tanganyika Basin and Lake Rukwa Basin. Tanzania participates in Commissions and Secretariats which were established to oversee and manage the above basins.

\section{The National Water Policy 2002}

The National Water Policy contains statements on transboundary waters. ${ }^{22}$ It calls for the government to sustain and expand international cooperation in planning and monitoring transboundary waters resources in accordance with principles of justice and equitable utilisation. ${ }^{23}$ A priority shall be given to technical cooperation (especially regarding research), data collection, and information sharing. It also recognizes that dialogue and cooperation are invaluable as far as ownership, sustainable use, and management of these water resources are concerned.

It identifies unique challenges facing transboundary waters such as preventing and cleaning water pollution, removing hyacinth weed, reforming poor laws regarding waste disposal and discharge in the rivers, diverting water from one basin to the other, managing water basins for construction of water irrigation and electricity projects, and generally protecting the environment and promoting biodiversity. ${ }^{24}$

Accordingly, the national Water Policy calls for the government to (a) assess and document national priorities in the use and management of water resources within the existing shared water basins and in collaboration with national authorities, (b) put in place a mechanism ensuring that water basins in the shared rivers and lakes are effectively used to meet the demand of social services and national economic activities on the basis of equality, justice, and equitable utilisation, and (c) establish a system of managing water resources within international water basins, in promotion of international cooperation.

In implementing the National Water Policy, the government enacted the Water Resources Management Act No.11 of 2009 and the Water Supply and Sanitation Act No. 12 of 2009 .

$(\mathrm{Mb})$, Akiwasilisha Bungeni Mpango na Makadirio ya Matumizi ya Fedha ya Wizara ya Maji kwa Mwaka 2012/2013, 52-56.

22 National Water Policy 2002, paras 33(at 13) and 4.9 (at 21-22).

23 "Ushirikiano wa aina zote kuhusu usimamizi wa rasilimali za maji ya kimataifa utazingatia misingi ya usawa na haki na kwa uwiano unaofaa", para 3.3.

24 National Water Policy 2002, para 4.9 (at 21-22). 


\section{The Water Resources Management Act of 2009}

The Water Resources Management Act deals with water resources by ensuring that resources are sustainably protected, used, developed, conserved, managed and controlled to meet the basic human needs of present and future generations under the concept intergenerational equity. It also seeks to facilitate the participation of stakeholders and the general public in implementation of the National Water Policy 2002.

Part XII of the Act regards transboundary waters. It vests powers in the Director of Water Resources in order to ensure sustainability, equitable utilization, and management of transboundary waters. ${ }^{25}$ It further establishes and designates the Director of Water Resources as the custodian of all international and regional agreements, to which Tanzania is a party, concerning the utilisation and management of transboundary waters. The Minister remains responsible for developing legislative and policy measures necessary for implementation of those agreements. ${ }^{26}$

The Minister is also tasked with ensuring data collection on various arrays concerning the utilisation and management of transboundary waters. ${ }^{27}$ This includes data and information on:

(a) the water balance for each transboundary water that compares forecasted water demand with data and information regarding water availability;

(b) the volume of water abstracted and beneficially used within Tanzania and other riparian states from each transboundary waters;

(c) the nature of the beneficial uses within Tanzania supported by each transboundary waters, including the economic value of the uses;

(d) the number of persons within Tanzania who rely upon each transboundary waters for domestic, agricultural, commercial or industrial purposes;

(e) the relevant date or dates upon which the abstraction of water from each transboundary waters for beneficial use within Tanzania commenced;

(f) the availability and reliability of alternative sources of water to support existing beneficial uses within Tanzania in the event abstractions from transboundary waters are curtailed;

(g) anticipated increases in demand for water from each transboundary waters reasonably expected to occur within Tanzania in the foreseeable future;

(h) the volume and composition of waste discharged from within Tanzania into each transboundary waters;

(i) the relevant date or dates upon which the discharge into each transboundary waters commenced;

25 Section 98(1) of the Act.

26 Section 98(2) of the Act.

27 Section 100 of the Act. 
(j) the environmental integrity of transboundary waters and likely environmental threats including water pollution in the foreseeable future; and

(k) the availability and reliability of alternative means of waste disposal within Tanzania in the event discharges into transboundary waters are curtailed.

Furthermore the Minister is required under the Act to develop a common database on the use of transboundary waters with neighbouring riparian states, and to promote economic growth, equitable utilisation of water resources, and environmental integrity by encouraging other riparian states to form joint projects and management plans. He or she is also required to promote international cooperation by ensuring the effective participation of Tanzania in relevant international river basin organizations. Additionally, the Minister is required to establish or participate in the establishment of mechanisms for the prevention, management, and resolution of disputes relating to transboundary waters. ${ }^{28}$

Most of the above data and information is presented annually to the National Assembly through the Ministerial Budgetary speeches. This gives parliamentarians an opportunity to supervise the administration in its handling of commitments relating to transboundary water arrangements. It has been reported that on 8 February 2010, Tanzania ratified the agreement to establish the Zambezi Watercourse Commission of 2004 (ZAMCOM) regarding the management of the Zambezi Water Basin on river Zambezi. The ZAMCOM signatories include Angola, Namibia, Zambia, Zimbabwe, Botswana, Malawi and Mozambique. In April 2012, Tanzania set up a national committee to coordinate ZAMCOM activities. In 2012, Tanzania and Kenya signed a Memorandum of Understanding (MoU) within the framework of the Lake Victoria Basin to sustainably manage the ecology of Lake Chala and Jipe as well as the Umba River. Tanzania also participated in the Secretariat for Lake Tanganyika Basin which aims to address the ongoing problem of the reduction of water in Lake Tanganyika since $2011 .^{29}$

\section{The EAC Framework: The Treaty for Establishment of the East African Community 1999}

The EAC has no specific instruments for the management of transboundary waters. However, the Treaty for the Establishment of the East African Community 1999 has a chapter on cooperation in environmental and natural resources management. ${ }^{30}$ It calls for concerted efforts in ensuring sustainable utilisation of natural resources like lakes, wetlands, forests

28 Section 99 of the Act.

29 For instance see Wizara ya Maji, note 20.

30 Chapter 19 of the Treaty for the Establishment of East African Community 1999. Also see James Forole Jarso, The East African Community and the Climate Change Agenda: An Inventory of the Progress, Hurdles, and Prospects, Sustainable Development Law \& Policy 12 (2012), 19; Carl Bruch and Roman Czebiniak, Globalizing Environmental Governance: Making the Leap From Regional Initiatives on Transparency, Participation, and Accountability in Environmental Matters, ELR 32 (2002), 10442-10443. 
and other aquatic and terrestrial ecosystems within the region. It requires states to jointly develop and adopt water resource conservation and management policies that ensure sustenance and preservation of ecosystems. ${ }^{31}$ It is noteworthy that the International Court of Justice in 1997 held that the emerging norms of environmental law are relevant in the implementation of the water resource related obligations. This was held in the protracted case of Gabcikovo-Nagymaros Project between Hungary and Slovakia and concerned the construction of hydro-electric power dam by Slovakia along the river Danube which affected Hungary's access to water. ${ }^{32}$

Since "trans-boundary environment" includes transboundary waters, the framework under this Treaty is relevant for the transboundary waters. ${ }^{33}$ For instance Article 112 specifically requires the partner states to take measures to control trans-boundary water pollution arising from developmental activities and to harmonise their policies and regulations for sustainable and integrated management of shared natural resources and ecosystems. ${ }^{34}$

The EAC has designated Lake Victoria and its Basin as an area of common economic interest and a regional economic growth zone to be developed jointly by all the partner states. Accordingly, in 2004 the Lake Victoria Basin Commission, based in Kisumu Kenya, has been established as a mechanism for the management, coordination, rational utilization, and various interventions on behalf of the Lake and its Basin as shared resources. ${ }^{35}$ Notable among projects being undertaken by the Commission are one regarding the strengthening of institutional capacity for managing shared water resources and the Mara River Basin management Initiative. The Lake Victoria Basin Commission is regarded as a specialized institution within the EAC that is responsible for coordinating the sustainable development agenda of the Lake Victoria Basin by providing equitable opportunities and benefits. ${ }^{36}$

The EAC is also associated with the Nile Basin Initiative (NBI) and other riparian states on river Nile. Lake Victoria is the major source of river Nile. The NBI seeks to promote equitable utilization and management of the Nile basin resources, prevent environmental harm, and replace British colonial agreements on the access and use of Nile water resources, which gave a priority to the needs of Egypt and Sudan as the lower riparians. In

31 Article 111 of the Treaty for the Establishment of East African Community 1999.

32 See Gabcikovo-Nagymaros Project case (Hungary/Slovakia) (ICJ 1997), http://www.icj-cij.org/do cket/index.php?pr=267\&p1 $=3 \& p 2=1 \&$ case $=92 \& p 3=6$ (accessed on 26 December 2014).

33 Also see Angela Cassar and Carl Bruch, Transboundary Environmental Impact Assessment in International Watercourse Management, N.Y.U. Environmental Law Journal 12 (2003), 212-215.

34 Article 112(1)(c) and 112(2)(j) of the Treaty for the Establishment of East African Community 1999. Also see Carl Brunch, Charting New Waters: Public Involvement in the Management of International Watercourses, ELR 31 (2001), 11392 \& 11402.

35 For an overview of Lake Victoria Basin Commission see http://www.lvbcom.org/index.php/whowe-are/overview-of-lvbc (accessed on 26 December 2014).

36 See http://www.environment.eac.int/index.php?option=com_content\&view=article\&id=53:lake-vi ctoria-basin-commission\&catid=25:eac-gender (accessed on 26 December 2014). 
1999, the Nile Basin Cooperative Framework Agreement (CFA) was developed and signed by all EAC partner states along with Ethiopia.

The EAC has adopted Regional Guidelines on Environmental Impact Assessment of Shared Ecosystems. ${ }^{37}$ Environmental Impact Assessment development projects will serve to promote environmental conservation, social responsibility, economic cooperation, sustainability. ${ }^{38}$ Under its guidelines, the potential activities and projects to be regulated will include waste disposal installations, large weed and pest control programs, large dams and reservoirs, inland waterways and ports, groundwater abstraction activities in cases where the annual volume of water to be abstracted amounts to 10 million cubic meters or more, water management projects for agriculture such as irrigation and land drainage projects, construction of hydroelectric power and overhead electrical power lines with a voltage of 220 kilovolts or more and a length of 15 kilometres or more and other projects for the transmission of electrical energy by overhead cables. ${ }^{39}$

It worth noting that the EAC is also developing a full-fledged Protocol on Environment and Natural Resources Management that will implement relevant provision of the Treaty on sustainable and integrated management of shared natural resources and transboundary ecosystems. The Protocol seeks to enable partner states to jointly develop and adopt harmonized common policies and strategies for sustainable management of transboundary natural resources. ${ }^{40}$ The draft Protocol on Environment and Natural Resources Management calls for Partner States, in situations involving transboundary issues, to manage the environment and natural resources under the principles of: prior informed consent or notification, cooperation in the management of transboundary environment and natural resources, unity and coherence of shared ecosystems, inter and intra generational equity, prevention of significant harm, precautionary, and polluter or user pays. ${ }^{41}$ It incorporates all relevant principles of international environmental law as into the environmental laws of the community. ${ }^{42}$

Article 13 of the draft Protocol on Environment and Natural Resources Management deals with management of water resources and requires Partner States to utilize water resources, including shared water resources, in an equitable and rational manner. It also commits partner states to develop, harmonise and adopt common national policies, laws, and programmes relating to the management and sustainable use of water resources. Specifically, partner states are urged to cooperate (a) in the management of shared water resources, which may include the establishment of joint management mechanisms, (b) management

37 Transboundary Environmental Assessment Guidelines for Shared Ecosystems in East Africa, 2005. Also see Cassar, note 32, 212-215.

38 Environmental Impact Assessment, at http://www.environment.eac.int/ (accessed on 26 December 2014).

39 Annex A - Transboundary Environmental Assessment Guidelines for Shared Ecosystems in East Africa, 2005.

40 Article 9 of the Protocol on Environnent and Natural Ressources Management.

41 Article 4 of the Protocol on Environment and Natural Resources Management.

42 Article 42 of the Protocol on Environment and Natural Resources Management. 
and execution of all projects likely to have an effect on shared water resources, (c) respond to the needs or opportunities arising from the regulation of the flow of the waters of shared water resources, (d) develop and use water resources for the purpose of attaining optimal and sustainable utilization thereof and procuring benefits there from, consistent with the adequate protection of those water resources, (e) prevent or mitigate conditions related to shared water resources that may be harmful to other partner states, whether resulting from natural causes or human activities, and (f) protect and conserve biological diversity in the shared water resources.

This protocol provides a dispute settlement mechanism. In the event of a dispute between partner states on the interpretation or application of the protocol, the concerned states shall seek a settlement of the dispute through negotiations or other alternative dispute resolution mechanisms. In the event an agreement is not reached, the dispute may then be filed with the East African Court of Justice whose decision is final. ${ }^{43}$

The draft Protocol on Environment and Natural Resources is not yet ratified due to a number of reservations made during the process. In September 2014, the Council of the EAC Ministers directed the Secretariat to convene a meeting of the Sectoral Council on Environment and Natural Resources to study the contentious provisions of the Protocol. The contentious issues, raised by the United Republic of Tanzania, include provisions that contravene the EAC Common Market Protocol, lack of clarity of core terminologies, and cover issues beyond environment and natural resources. ${ }^{44}$

\section{The SADC Framework: Revised Protocol of Shared Watercourses in the SADC 2000}

The Revised Protocol of Shared Watercourses in the SADC of 2000 is the only regional instrument regulating common management and utilization of the shared watercourse resources in the SADC region, which is comprised of 15 states in sub-Saharan Africa. The preamble to this Protocol affirms that it will pay due consideration to the progress made by the 1966 Helsinki Rules, which asserted the rights of bordering nations to an equitable share of water resources, with 'reasonable consideration of such factors as past customary usages of the resource and balancing variant needs and demands of the bordering nations. ${ }^{45}$ The preamble also affirms the commitment to the UN Convention on the Law of the Non-Navigational Uses of International Watercourses 1997 which addressed the weaknesses of the Helsinki Rules, especially the omitted aspects on independent aquifers. Furthermore, the Protocol recognizes the importance of the 1992 Agenda 21 of the United Na-

43 Article 41 of the Protocol on Environment and Natural Resources Management.

44 Report of the $29^{\text {th }}$ Meeting of the Council, 15-20 September 2014, Arusha Tanzania, 8-9.

45 See http://en.wikipedia.org/wiki/The_Helsinki_Rules_on_the_Uses_of_the_Waters_of_Internation al_Rivers, (accessed on 18 December 2014); Protocol of Shared Watercourses in the SADC http:// www.orangesenqurak.org/governance/water+resource+management+southern+africa/sadc+water+ protocol.aspx (accessed on 18 December 2014). 
tions Conference on Environment and Development adopted in Rio, the concepts of environmentally sound management, sustainable development, and equitable utilization of shared watercourses in the region. The original Protocol of Shared Watercourses in the SADC which emphasized the principle of territorial sovereignty was concluded in 1995 and was modelled on the Helsinki Rules of 1966. The revised protocol stresses the importance of taking a basin wide approach to water management and integrated water resources management. ${ }^{46}$

The Protocol defines "shared watercourse" as any watercourse passing through or forming the border between two or more member states of SADC. Watercourse covers a system of surface and ground waters consisting of, by virtue of their physical relationship, a unitary whole normally flowing into a common terminus such as the sea, lake, or aquifer. ${ }^{47}$ The Protocol seeks to promote and facilitate the establishment of shared watercourse agreements and shared watercourse institutions for the management of shared watercourses and also to advance the sustainable, equitable and reasonable utilization of the shared watercourses. ${ }^{48}$ This is crucial in SADC where $70 \%$ of freshwater resources are being shared by two or more countries. ${ }^{49}$

The Protocol recognizes the principles of unity and coherence for each shared watercourse to which all water uses must adhere. In addition, sustainable, equitable, and reasonable utilization of shared watercourse is very much encouraged by the Protocol. Article 3(7) categorically requires shared watercourses to be used and developed with the purpose of attaining optimal and sustainable utilization thereof for the benefit of current and future generations. It therefore provides both the right to utilize watercourses and the duty to cooperate in their protection and development.

In determining the equitable and reasonable utilization of shared watercourses, the minimal factors and circumstances to be considered by each state party include (a) geographical, hydrographical, hydrological, climatic, ecological and other factors of a natural character, (b) the social, economic and environmental needs of the watercourse states concerned, (c) the population dependent on the shared watercourse in each watercourse state, (d) the effects of the use or uses of a shared watercourses of one watercourse state on other watercourse states, (e) existing and potential uses of the shared watercourse, (f) conservation, protection, development and economy of use of the water resources of the shared water-

46 See the Protocol of Shared Watercourses in the SADC http://www.orangesenqurak.org/governance /water+resource+management+southern+africa/sadc+water+protocol.aspx (accessed on 18 December 2014); Nola Redelinghuys, International Conflict over Fresh Water Resources: the Formulation of Preventive and Interventive Guidelines, A Thesis for the Degree Philosophiae Doctor in the Faculty of the Humanities, Department of Sociology, the University of the Free State Bloemfontein, 2008, 162-165; Nola Redelynghus and André Pelser, Challenges to Cooperation on Water Utilisation in the Southern African Region, 15 Water Policy 15 (2013), 554.

47 Article 1 of the Protocol.

48 Article 2 of the Protocol.

49 Redelinghuys, note $45,162$. 
course and the costs of measures taken to that effect, and (g) the availability of alternatives, of comparable value, to a particular planned or existing use. ${ }^{50}$ All the above factors must be considered together and a decision shall be reached on the basis of the whole in determining the equitable and reasonable utilization of shared watercourses. In doing so, a relative weight shall be assigned to each factor in proportion to its importance and relevance to the determination. 51

The protocol requires all state parties utilizing a shared watercourse in their territories, to take all appropriate measures to prevent the infliction of significant harm to other watercourse states. ${ }^{52}$ This is the environmental law principle which seeks to prevent water pollution and degradation. The Protocol also requires countries to, individually and, where appropriate, jointly, protect and preserve the ecosystems of a shared watercourse.

It obliges state parties to exchange data and information regarding the hydrological, hydro geological, water quality, meteorological and environmental condition of shared resources. ${ }^{53}$ State parties are also obliged to consult each other and, if necessary, negotiate the possible effects of planned measures on the condition of a shared watercourse. ${ }^{54}$ Furthermore, the Protocol allows partner states to enter into bilateral or multilateral agreements with each other regarding provisions of the protocol in their shared watercourses, provided such agreements bear no adverse effects on other non-members. ${ }^{55}$

In terms of institutional framework for the implementation of the Protocol, several institutional mechanisms designated as SDAC Water Sector Organs have been created to oversee the implementation of the protocol. This includes the Committee of Water Ministers, the Committee of Water Senior Officials, the Water Sector Coordinating Unit and the Water Resources Technical Committee and Sub-Committees as well as shared Watercourse Institutions. ${ }^{56}$

More importantly, the Protocol provides a dispute resolution mechanism. It calls for parties to resolve their disputes, regarding the interpretation or application of the Protocol, amicably. If a dispute remains unresolved, then it will be referred to the SADC Tribunal

50 Article 3(8) of the Protocol.

51 Article 3(8) of the Protocol.

52 Article 3(10) of the Protocol.

53 Article 3(6) of the Protocol.

54 Article 4(1) of the Protocol.

55 Article 6(3) of the Protocol. River basin organisations under SADC for which Tanzania is a party includes (a) the Lake Tanganyika Authority established by the governments of Burundi, Democratic Republic of Congo, Tanzania, and Zambia, (b) the Ruvuma Joint Water Commission between the Republic of Mozambique and the United Republic of Tanzania on Ruvuma River basin, (c) the Zambezi Watercourse Commission of 2004 which includes seven of the eight Zambezi Riparian States (Zambia, Angola, Namibia, Zimbabwe, Botswana, Malawi, Tanzania and Mozambique), (d) the Pangani River Basin shared by Kenya and Tanzania, and (e) Congo River Basin.

56 Article 5 of the Protocol. 
whose decision shall be binding and final. ${ }^{57}$ The Tribunal also has the power to render advisory opinions at the request of the Summit of the Heads of State or Government or the Council of Ministers of SADC ${ }^{58}$ for disputes between a SADC member and a non-member on shared watercourse. ${ }^{59}$

Unfortunately, the SADC Tribunal has been indefinitely suspended since 2010 after holding Zimbabwe liable for violating the human rights and rule of law provisions of the SADC Treaty. ${ }^{60}$ The Summit of the Heads of State, or the Government of SADC, resolved in 2012 that a new protocol on the Tribunal should be negotiated and its mandate be should confined to interpretation of the SADC Treaty and Protocols relating to disputes between Member States only instead of disputes between Member States and persons. The Attorneys General of the SADC has been tasked with preparing the new Protocol on the Tribunal to make it an interstate court. At the same time, various individuals and organisations are protesting the process of making the Tribunal an interstate court. ${ }^{61}$ The absence of the Tribunal is a serious weakness of the entire disputes resolution mechanism under the Protocol.

It is noteworthy that within the SADC, Malawi and Tanzania are still having an unresolved, longstanding colonial border conflict over Lake Nysasa as a shared watercourse. The struggle dates back to the 1960's when tensions rose between the former heads of states, the late Mwalimu Julius Nyerere of Tanzania, supporter of the liberation struggle against the apartheid regime of South Africa and Dr. Hastings Kamuzu Banda of Malawi, the staunch supporter of the apartheid government of South Africa. Their ideological differences prevented a cooperative effort from occurring. To date, Malawi is still of the opinion that the lake exclusively belongs to her and the boundaries lie within the shores of the lake, which are between the two countries. This conjecture is predicated upon the Anglo-German Treaty of 1890 which granted sole jurisdiction of the lake's waters to Malawi. At the same time, Tanzania claims that the border runs through the middle of the lake as per, among other things, the 1954 agreement was signed between the British and the Portuguese making the middle of the lake their boundary with the exception of Chizumulu Island and Likoma Island which were kept by the British and are now part of Malawi. ${ }^{62}$ In 2012 a border

57 Article 16 of the Treaty of the Southern Africa Development Community 1992.

58 Article 9 of the Treaty of the Southern Africa Development Community 1992.

59 Article 7 of the Protocol.

60 Karen Alter, LR Helfer and JR McAllister, A New International Human Rights Court for West Africa: The ECOWAS Community Court of Justice, American Journal of International Law 107 (2013), 777.

61 For instance, the Tanganyika Law Society (TLS), the Bar Association of Tanzania, is now challenging the suspension of SADC Tribunal in court of law in Tanzania. Other bar associations are doing the same in their countries. See TLS v. Ministry of Foreign Affairs of Tanzania \& Attorney General of Tanzania, Misc Civil Cause No. 23 of 2014 at the High Court of Tanzania at Dar es Salaam (Main Registry); before Justices Lila J; Mujulizi J; and Bongole, J.

62 James Mayall, The Malawi-Tanzania Boundary Dispute, The Journal of Modern African Studies 11(4) (1973), 618-620. Also see http://en.wikipedia.org/wiki/Lake_Malawi\#Tanzania.E2.80.93Ma lawi_dispute (accessed on 12 April 2014). 
conflict between Tanzania and Malawi rose and took a new turn when Malawi began oil exploration in the lake along Tanzanian waters. Tanzania demanded immediate stoppage of the exploration and the tension between the two countries was so high that it forced the two governments to convene a dialogue. ${ }^{63}$

\section{UN Convention on the Law of the Non-Navigational Uses of International Watercourses 1997}

Tanzania abstained from voting for the adoption of the UN Convention on the Law of the Non-Navigational Uses of International Watercourses 1997. The Convention came into force on 17 August 2014 after achieving the required threshold of ratifications and the lapse of 90 days after the $35^{\text {th }}$ depository of the ratification instruments. ${ }^{64}$ However, given the fact that this Convention is the only and the first international instrument on shared water resources, it is necessary to discuss its purview.

The bedrock of this Treaty is built of two key principles, namely the equitable and reasonable use of shared watercourses and the obligation to not cause significant harm to neighbours. ${ }^{65}$ State parties are left to spell out the content of these principles in their own settings within their watersheds. ${ }^{66}$ The principle of equitable utilization in the context of community of interest of riparian state may be traced to the 1929 decision of the Permanent Court of International Justice on the matter relating to the authority of the Permanent Commission of the River Oder between Germany and Poland ${ }^{67}$ It was later endorsed by the International Law Association in the Helsinki Rules on the Uses of the Waters of International Rivers in 1966 and in the Berlin Rules on Water Resources in 2004. The principle is now regarded as the rule of customary international law and is founded upon the concept of an international drainage basin as a coherent juridical and managerial unit. ${ }^{68}$

Furthermore, Article 6 of the U.N. Convention provides factors to be considered in evaluating claims relating to equitable utilization, which are similar to those of the SADC Protocol and the Helsinki Rules, namely: “(a) geographic, hydrographical, hydrological, climatic, ecological, and other factors of a natural character; (b) the social and economic needs of the watercourse States concerned; (c) the effects of the use or uses of the water-

63 Legal and Human Rights Centre, Tanzania Human Rights Report 2012, 2013, 90-91.

64 Article 36(1) of UN Convention on the Law of the Non-Navigational Uses of International Watercourses 1997.

65 Article 5 and 7 of UN Convention on the Law of the Non-Navigational Uses of International Watercourses 1997.

66 International Decade for Action, note 7.

67 See Territorial Jurisdiction of the International Commission of the River Oder Case (Germany v. Poland), 1929 P.C.I.J. (ser. A) No. 23 as discussed in Joseph Dellapenna, A Climate of Disruption: Legal Measures for Adaptation and Mitigation: International Water Law in a Climate of Disruption, Michigan State Journal of International Law 17 (2008), 70-72.

68 Dellapenna, note 66, 72. 
course in one watercourse State on other watercourse States; (d) existing and potential uses of the watercourse; (e) conservation, protection, development and economy of use of the water resources of the watercourse and the costs of measures taken to that effect; and (f) the availability of alternatives, or corresponding value, to a particular planned or existing use." $" 69$

The principle of not causing harm to one's neighbours is basically an environmental law principle associated with the "polluter pays" principle, in which a polluting country or party is responsible for damages caused by the pollution. The principle can be traced back to the 1941 decision in the Trail Smelter Arbitration Tribunal which held that a "State owes at all times a duty to protect other States against injurious acts by individuals from within its jurisdiction." ${ }^{70}$ Although the Trail Smelter Arbitration Tribunal concerned transboundary air pollution between Canada and the US, the decision is none the less the defining precedent for transboundary pollution liability through any media, including water. ${ }^{71}$ This precedent was incorporated into Principle 21 of the United Nations Conference on the Human Environment Stockholm Declaration of 1972 and later reaffirmed in Principle 2 of the United Nations Conference on Environment and Development Rio Declaration of 1992 that: "States have, in accordance with the Charter of the United Nations and the principles of international law, the sovereign right to exploit their own resources pursuant to their own environmental policies, and the responsibility to ensure that activities within their jurisdiction or control do not cause damage to the environment of other States or of areas beyond the limits of national jurisdiction". ${ }^{72}$ Before the Trail Smelter Arbitration Tribunal precedent, the concept of absolute territorial sovereignty was applied in cases of transboundary pollution. One of the leading cases is the 1895 dispute between Mexico and the United States, in which the US farmers diverted water from the Rio Grande for irrigation and thereby reduced waters for the Mexicans. The Attorney General Judson Harmon of the US opined that "the United States was under no international legal obligation to hinder its development to protect the environment of its downstream neighbor," in what became to be known as the Harmon Doctrine of absolute territorial sovereignty. ${ }^{73}$

The UN Convention on the Law of the Non-Navigational Uses of International Watercourses 1997 requires watercourse states to collect and exchange data and information on

69 Also see Antonio Herman Benjamin, Claudia Lima Marques, and Catherine Tinker, The Water Giant Awakes: An Overview of Water Law in Brazil, Texas Law Review 83 (2005), 2225; Dellapenna, note 66, 75 .

70 Trail Smelter Arbitration Tribunal (U.S. v. Can.), 3 R.I.A.A. 1911 (1938).

71 Noah Hall, Boundary Waters Treaty Centennial Symposium: Introduction-The Centennial of the Boundary Waters Treaty: A Century of United States-Canadian Transboundary Water Management, Wayne Law Review 54 (2008), 1425-1426.

72 Principle 21 of the United Nations Conference on the Human Environment Stockholm Declaration of 1972; Principle 2 of the United Nations Conference on Environment and Development Rio Declaration of 1992.

73 Noah Hall, Transboundary Pollution: Harmonizing International and Domestic Law, University of Michigan Journal of Law Reform 40 (2007), 692-693. 
hydrological, meteorological, hydrogeological and ecological nature related to water quality and forecasts. ${ }^{74}$ It mandates that states consult and negotiate about possible effects of planned measures on the shared watercourse. Timely notifications to all watercourse states likely to be adversely affected by the implementation of the planned measures must be provided in order to eliminate or mitigate harm as well as to facilitating the agreement on compensation measures, if they are necessary. ${ }^{75}$ Such notification must include data on results of environmental impact assessments and all necessary technical data. ${ }^{76}$ All consultations and negotiations are to be done on the basis of good faith, taking into account the reasonable rights and the legitimate interests of parties. ${ }^{77}$ Accordingly, the notifying state is prohibited from implementing the planned measures without the consent of the notified states. ${ }^{78}$ The notification obligation also covers emergency situations arising from natural causes, which causes harm or has the potential to cause harm to the shared watercourses. In this case, a watercourse state, in whose territory an emergency originates, must notify other potentially affected states and competent international organisations. ${ }^{79}$

The UN Convention on the Law of the Non-Navigational Uses of International Watercourses 1997 provides details for the dispute settlement mechanism. It encourages peaceful settlement of any dispute arising out of the interpretation or application of the Convention in the first instance. In case the dispute is not settled, parties are urged to use the mediation services of good offices, request mediation or conciliation by a third party, or any joint watercourse institutions. Finally, the dispute may be lodged with any agreed upon arbitration tribunal or with the International Court of Justice ${ }^{80}$ Furthermore, article 32 of the UN Convention on the Law of the Non-Navigational Uses of International Watercourses 1997 allows all persons, natural or juridical, who have suffered or are under the threat of suffering transboundary harm on the shared watercourses, to seek remedy from national courts in a territory where the alleged activities took place, irrespective of their nationalities or where the injury occurred.

74 Article 9 of UN Convention on the Law of the Non-Navigational Uses of International Watercourses 1997.

75 Articles 7(b), 11 and 12 of UN Convention on the Law of the Non-Navigational Uses of International Watercourses 1997.

76 Bruch and Czebiniak, note 29, 11397; McIntyre, note 18, 185.

77 Article 17(2) of UN Convention on the Law of the Non-Navigational Uses of International Watercourses 1997.

78 Article 14(b) of UN Convention on the Law of the Non-Navigational Uses of International Watercourses 1997.

79 Part V of the UN Convention on the Law of the Non-Navigational Uses of International Watercourses 1997.

80 Article 33 of the UN Convention on the Law of the Non-Navigational Uses of International Watercourses 1997. 


\section{Tanzania and the UN Convention on the Law of the Non-Navigational Uses of International Watercourses 1997}

It is intriguing that Tanzania has neither signed nor ratified the UN Convention on the NonNavigational Uses of Transboundary Watercourses. According to Salman M. A. Salman, Tanzania, together with other Nile riparians, is reluctant to do so because of the controversies surrounding the legality of the Nile treaties of 1902, 1929 and 1959. "They do not want to be parties to a Convention that includes clear and detailed obligations for the notification of other riparians of planned measures and projects in their territories that may affect the Nile. ${ }^{81}$ They are concerned that such notification obligations would be construed by Egypt and Sudan as recognition of the 1902 and 1929 treaties that give Egypt and Sudan veto power over upstream activities". ${ }^{82}$ Article 3(1) of the UN Convention on the Non-Navigational Uses of Transboundary Watercourses saves all the agreements in force on the date of its enactment. Egypt and Sudan claim 'their historical rights and uses and both believe that the UN Watercourses Convention tilts towards equitable and reasonable utilization at the expense of the obligation not to cause significant harm. ${ }^{83}$

Salman argues that Egypt and Sudan need to drop their lion share's claim out of the flow of Nile so that a new and genuine spirit for cooperation among the Nile states can begin through an equitable sharing of the benefits of the common Nile waters without real harm to either Egypt or Sudan. ${ }^{84}$ Indeed, the colonial Nile treaties of 1902, 1929 and 1959 which gave veto powers to Egypt and Sudan, as the lower riparian states, over activities of all the upper riparian states can not stand the conscience of the time as they undermine the very principles of the UN Charter of sovereign equality and territorial integrity as the bedrock of international relations. ${ }^{85}$ It is no wonder that they are non-functional after having been 'totally ignored by the other riparians, both in theory and in practice. ${ }^{86}$ Furthermore, it is noteworthy that when Tanzania became independent from British colonial rule in 1961 , it inherited no obligation to abide by treaties signed by her colonial master. ${ }^{87}$ As the country was a colonial state, the rule of continuity for separating states is not applicable to it under the Vienna Convention on Succession of States in Respect of Treaties of 1978 as it

81 Part III of the UN Convention on the Non-Navigational Uses of Transboundary Watercourses 1997.

82 Salman Salman, Entry into Force of the UN Watercourses Convention - Where are the Nile Basin Countries?, http://www.internationalwaterlaw.org/blog/2014/06/02/dr-salman-m-a-salman-e ntry-into-force-of-the-un-watercourses-convention-where-are-the-nile-basin-countries/ (accessed on 19 December 2014).

83 Salman, note 81.

84 Salman, note 81.

85 Also see Article 8(1) of UN Convention on the Non-Navigational Uses of Transboundary Watercourses 1997.

86 Salman, note 81.

87 Article 2(f) and 8(1) of Vienna Convention on Succession of States in Respect of Treaties of 1978. 
was not a mere change of regime. ${ }^{88}$ Accordingly, under the clean slate doctrine, Tanzania can't be held accountable to for treaties that were entered into non-consensually, in the interest of the colonial master, as the colony became an independent state. ${ }^{89}$ Article 16 of Vienna Convention on Succession of States in Respect of Treaties of 1978 is clear on the position of the treaties regarding the predecessor State. It provides that "a newly independent State is not bound to maintain in force, or to become a party to, any treaty by reason only of the fact that at the date of the succession of States the treaty was in force in respect of the territory to which the succession of States relates". In any case, no single country may decide the fate of the Nile river and all riparians need to agree and cooperate in good faith for the benefits of all.

The other possible reason for the non-ratification of the UN Convention on the NonNavigational Uses of Transboundary Watercourses is the fact that SADC Protocol is a locally negotiated instrument which covers essentially all the aspirations of the UN Convention. Arguably, SADC states are already implementing what is required of them under said UN Treaty. Article 8(2) of the UN Convention encourages watercourse states to establish joint mechanisms as deemed necessary to facilitate cooperation on any relevant measures in light of experiences gained through cooperation in existing joint mechanisms in various regions. The cooperation on shared watercourses within SADC dates back to 1987 when the Action Plan for the Common Zambezi river system was developed, and the same was later expanded into a Protocol on Shared Watercourse Systems in 1995. The current SADC Protocol of 2000 is a revised version of the 1995 Protocol and it is modelled on the UN Convention along the lines of information exchange and technical consultations among the riparians on the basis of sovereign equality, territorial integrity, and mutual benefit rather than an actual decision making body. ${ }^{90}$

This should not suggest the absence of differences between the UN Convention on the Non-Navigational Uses of Transboundary Watercourses and the SADC Protocol. According to the UN Watercourses Convention User's Guide Fact Sheet Series, Article 2 of the SADC Revised Protocol gives special emphasis to prioritising the regional integration and poverty alleviation of States when balancing competing uses of a watercourse. Furthermore, the UN Convention is widely perceived to prioritise the principle of equitable and reasonable utilisation over the rule of no significant harm as Article 7 of the UN Convention on the rule of no significant harm obligates States to consider equitable and reasonable utilisation whenever harm occurs to another State. Under SADC Protocol, the obligation of no significant harm does not specifically refer to the principle of equitable and reasonable utilisation. It has been argued that this distinction may have practical applications for the inter-

88 Andrew Beato, Newly Independent and Separating States' Succession to Treaties: Considerations on the Hybrid Dependency of the Republics of the Former Soviet Union, American University International Law Review 9(2) (1994), 556.

89 C. Emanuelli, State Succession, Then and Now, With Special Reference to the Louisiana Purchase, http://digitalcommons.law.lsu.edu/lalrev/vol63/iss4/19 (accessed on 19 December 2014).

90 Joseph Dellapenna, 3-49 Waters and Water Rights § 49.04. 
pretation of laws regarding planned measures and disputes concerning allegations of significant harm being caused by another State.

\section{Areas for Reforms: Discussion}

The management of shared watercourses among riparians is a complex issue. As such, there is no universal framework which fits all scenarios. However, there are some generally acceptable standards which a workable and viable scheme on trans-boundary waters may exist and be assessed. It has been argued that "there is a consensus among experts that international watercourse agreements need to be more concrete, setting out measures to enforce treaties made and incorporating detailed conflict resolution mechanisms in case disputes erupt." And that a "better cooperation also entails identifying clear yet flexible water allocations and water quality standards, taking into account hydrological events, changing basin dynamics and societal values". ${ }^{91}$ In these premises, there are three areas of weaknesses from the standpoint of Tanzania which are noteworthy, namely the statuses of groundwater, watercourses with Zanzibar, and the limitations of the dispute settlement mechanism.

\section{The Status of Groundwater}

Both the SADC Protocol and the UN Convention on the Non-Navigational Uses of International Watercourses 1997 share an identical definition of "watercourse" as being a system of surface and ground waters constituting, by virtue of their physical relationship, a unitary whole and normally flowing into a common terminus such as the sea, lake or aquifer. ${ }^{92}$ This definition equates surface water with ground water in general terms. ${ }^{93}$ However, the definition of ground water is inadequate, as it includes some types of aquifers, but not all, and therefore it is not comprehensive regarding the status of groundwater under international law. ${ }^{94}$ The definition covers aquifers that traverse international borders instead of all aquifers hydraulically related traverses or flows along an international border. ${ }^{95}$ According to Gabriel Eckstein and Yoram Eckstein ${ }^{96}$ aquifers are of many types and may also form transboundary waters in various ways including the following: First, an unconfined aquifer that is linked hydraulically with a river, both of which flow along an international border.

91 International Decade for Action, note 7.

92 Article 1 SADC Protocol and Article 2(a) UN Convention on the Non-Navigational Uses of Transboundary Watercourses 1997.

93 Fadia Daibes, International Perspective: A Progressive Multidisciplinary Approach for Resolving the Palestinian Israel Conflict over the Shared Transboundary Groundwater: What Lessons Learned from International Law?, University Denver Water Law Review 8 (2004), 115-116.

94 Benjamin, note 68, 2211.

95 Gabriel Eckstein and Yoram Eckstein, A Hydrogeological Approach to Transboundary Ground Water Resources and International Law, American University International Law Review 19 (2003), 230.

96 Eckstein and Eckstein, note 94, 236-249. 
That means an aquifer that is bisected by an interrelated river that forms a political boundary between two states, such as the Danube alluvial aquifer underneath the portion of the Danube River flowing between Croatia and Serbia. Second, an unconfined aquifer intersected by an international border and linked hydraulically with a river that is also intersected by the same international border, such as the Abbotsford-Sumas Aquifer between Canada and the United States or the Mures/Maros Aquifer underlying Hungary and Romania. Third, an unconfined aquifer that flows across an international border and hydraulically linked to a river that flows completely within the territory of one state, such as the Mimbres Basin Aquifer traversing northern Mexico and New Mexico of the U.S. Fourth, an unconfined aquifer that is completely within the territory of one state but linked hydraulically to a river flowing across an international border, such as the Gila River Basin Aquifer underneath parts of Arizona, California, Nevada, and New Mexico in the United States. Fifth, a confined aquifer, unconnected hydraulically with any surface body of water, with a zone of recharge that traverses an international boundary or that is located completely in another state, such as the aquifers in the Syr Darya River Basin, the Mountain Aquifer between Israel and the Palestinian Territories. Sixth, a transboundary aquifer unrelated to any surface body of water and devoid of any recharge, such as the Nubian Sandstone Aquifer underneath Chad, Egypt, Libya, and Sudan. From the above definitions, the confined groundwaters, those that do not share a common terminus with surface waters, would be excluded from the SADC Protocol and UN Convention on the Non-Navigational Uses of International Watercourses 1997, as groundwater has been largely "out of sight and out of mind in the practice of states." 97

The Tanzanian domestic legislation on shared watercourses is somewhat comprehensive as it covers all types of aquifers (confined or connected to the surface water, renewable or non-renewable for being detached to the hydrological cycle) provided they are contained within drainage or river basins shared or crossing international borders. Section 3 of the Water Resources Management Act 2009 defines transboundary waters as including water resources contained within drainage or river basins which cross the geographical boundaries of and are shared with more than one sovereign country. Water resources cover ground water naturally stored or flowing below the surface of the earth and which are not apparent on the surface. Water sources include aquifers of any kind.

As Faida Daibes puts it, much as the solution to crisis of fresh water may lay hidden underground, most underground waters remain formally unregulated. ${ }^{98}$ Despite the current recognition of the need to regulate a shared aquifer by treating it and subjecting it to the same rules as surface water in many existing international water treaties, more detailed and specific rules on groundwater are crucial. This includes legal aspects on the identification and scope of aquifers, rules on allocation and user rights, institutional and management framework, as well as dispute solving mechanism. According to Daibes, the existing multi-

97 Benjamin, note 68, 2224.

98 Daibes, note 92, 95. 
lateral treaties offer a good starting point in crafting ideal rules on groundwater. This includes The United Nations Convention on the Protection and Use of Transboundary Watercourses and International Lakes 1992 (Helsinki Convention), 1994 Danube River Basin Convention of Central Europe on river Danube, and the 1998 Convention on the Protection of the Rhine. ${ }^{99}$

\section{Watercourses with Zanzibar}

The United Republic of Tanzania is a sui generis unitary government with the autonomous revolutionary government of Zanzibar. Zanzibar got its own constitution in 1984, which is sovereign for all non-union matters. The government of the United Republic of Tanzania is responsible for all union matters and all maters relating to Mainland Tanzania. In this context, there is no transboundary waters between Tanzania and Zanzibar as the two constitutes one sovereign country. However, water is not a union matter, and the Minister for Water of Mainland Tanzania has no mandate regarding the waters of Zanzibar. At the same time, there is no organ or law at the union level for shared waters between the mainland and Zanzibar, even though Zanzibar is not a sovereign state for the water to qualify as transboundary waters. But there is transboundary waters between Zanzibar (as part of the United Republic of Tanzania) and other neighbouring countries which can not be negotiated through the Minister of water of mainland Tanzania under the Water Resources Management Act 2009. These are some of the grey areas that need to be addressed because the transboundary shared waters connected to Zanzibar can not be treated as a non-union matter.

Aquifers are the main shared watercourses that potentially connects Zanzibar with the neighbouring countries especially Kenya. Zanzibar has a widespread of unconfined aquifer with artesian conditions which may be hydraulically connected to the neighbouring countries. Most of the aquifers in question are too deep to be exploited. In general, Zanzibar (Unguja and Pemba islands) forms part of the ancient Rufiji/Ruvu delta of Miocene age which due to isostatic tectonic movements only the islands remain un-submerged. ${ }^{100}$ It is therefore hydraulically connected to Tanzania although Pemba is separated from it by a fault. Additionally, much as the two islands have similar hydrogeological systems, Pemba is formed exclusively of Miocene formations devoid of coral lime stones of Unguja. The Pemba's main water resources are found in the Miocene rocks. ${ }^{101}$ Zanzibar entirely depends on ground water (in the forms of springs, tube, bore holes and cave water) as it does not have any reliable source of surface water. ${ }^{102}$

99 Daibes, note 92, 115.

100 Said Ali Hamadi Vuai, Geochemical Characteristics of Spaleotherm Formation in Caves from Zanzibar Island, Tanzania, 2, http://omicsonline.org/scientific-reports/JGG-SR-505.pdf (accessed 10 February 2015).

101 British Geological Survey, United Republic of Tanzania, Zanzibar and Pemba, 287-289, http://w ww.bgs.ac.uk/sadcreports/tanzania1989undpgroundwater.pdf (accessed on 10 February 2015).

102 Vuai, note $99,1$. 


\section{Settlement of Disputes}

In Tanzania, the dispute settlement mechanism for shared watercourses is limited in the sense that national courts are devoid of jurisdiction to entertain cases involving extraterritorial activities or where the alleged environmental harm occurred beyond the borders of mainland Tanzania. That means litigants from abroad cannot use domestic courts for activities causing degradation or any harm to the shared waters beyond Tanzania. However, for harm occurred in the country, any person (citizen or otherwise) residing in Tanzania has a locus standi to bring an action and seek appropriate relief with respect to any breach, violation, or threat of breach or violation of any provision of the environmental laws or of any misuse of articles, substances, or natural resources. Any person may sue in his or her own interest, in the interest of another person, who is, for practical reasons, unable to bring such action, in the interest of or on behalf of a group or class of person whose interests are affected, in the public interest, and most uniquely, even in the interest of the environment or other habitats. ${ }^{103}$ This is very revolutionary for a person to sue in the interest of any habitats, such as the ecosystem of shared of a certain watercourse.

At the same time, the dispute mechanism under SADC Protocol is ineffective, as the tribunal has indefinitely been suspended and will only resume at the will of the Summit of Heads of States and government of SADC. It is also expected that the tribunal, henceforth, will be converted into an intra-state court in which individuals will no longer have access to it. This is contrary to the spirit of article 32 of the UN Convention on the Law of the NonNavigational Uses of International Watercourses 1997 which allows all persons, natural or juridical, who have suffered or under threat of suffering transboundary harm on the shared watercourses to seek remedy to national courts in a territory where the complained activities took place, irrespective of their nationalities or where the injury occurred. This principle of non-discrimination to justice is considered to be an emerging norm of customary international law. Already in Europe and North America, cases involving transboundary harm may be brought by individuals who otherwise may not have standing in such a court. ${ }^{104}$ Tanzania, and the SADC in general, needs to consider revising their instruments to allow free access to foreign litigants to domestic courts on transboundary pollution matters relating to shared watercourses.

It is also noteworthy that the dispute settlement mechanism under the UN Convention on the Law of the Non-Navigational Uses of International Watercourses 1997 is more elaborate and effective than what is provided for under the SADC Protocol. While both give priority to the amicable settlement of disputes, the UN Convention offers more avenues upon which a dispute may be handled if not resolved amicably among the parties. This in-

103 Section 202 of the Environmental Management Act, 2004, No. 20 of 2004.

104 Bruch and Czebiniak, note 29, 11408. 
cludes the use of good offices, mediation services, watercourse institutions, fact-find commissions and the International Court of Justice or to the arbitral tribunals. ${ }^{105}$

\section{Conclusions}

The policy and legal framework governing shared watercourses in Tanzania, including the SADC Protocol as well as the emerging EAC environmental protection structure, represents the contemporary principles governing transboundary waters. If well and fully implemented, together with other principles of international cooperation in management of environmental resources shared by two or more states as well as other principles of environment and sustainable development, it is capable of guaranteeing the equitable and reasonable use of shared watercourses and the obligation not to cause significant harm to the transboundary waters. Principles of environmental preservation and sustainable development include the principles of precaution, polluter pays, eco-system integrity, public participation in the development of policies, plans and processes for the management of the environment, access to justice principles, inter-generational and intra-generational equity, and common but differentiated responsibilities.

The need for the proper regulation of transboundary waters is a matter of the highest priority, given the depletion of quality and quantity of global freshwater. Shared water resources, both on surface and in ground, need clear and effective cooperation regarding water allocation and water quality standards among the riparians in order to sustainably manage them and to prevent conflicts among users and states. The emerging EAC framework, SADC Protocol, and the UN regime offer an unprecedented forum for Tanzania to negotiate and agree with its neighbours on the watercourses for which it has interests and shares. In this context, the draft EAC Protocol on Environment and Natural Resources Management needs to be reviewed and agreed among the partner states, and be operationalized as it contains crucial provisions on the managements of water resources. ${ }^{106}$ Tanzania should also reconsider its position to ratify the UN Convention on the Law of the Non-Navigational Uses of International Watercourses 1997 as the convention complements and reinforces the existing commitments under the SADC Protocol.

More importantly, Tanzania needs to address the known loopholes relating to the status of groundwater, watercourses with Zanzibar, and dispute settlement mechanisms for enforcing the relevant commitments referenced above. It is necessary that robust rules on aquifers are developed within the existing governing policy and legal framework governing water in Tanzania. Likewise, an organ and law responsible for management and administration of the transboundary waters touching Zanzibar be clearly spelt out. Tanzania should also allow its courts to entertain cases involving extraterritorial activities by Tanzanians or

105 Article 33 of the UN Convention on the Law of the Non-Navigational Uses of International Watercourses 1997.

106 Article 13 of the Protocol on Environment and Natural Resources Management. 
where the alleged environmental harm occurred beyond the borders of mainland Tanzania but originated in Tanzania. Also, the SADC Tribunal should also be revived and not be converted into an intra-state tribunal as it is currently being proposed. This is a critical body capable, if empowered, of mediating disputes amicable among within the SADC region which $70 \%$ of its freshwater resources is shared by two or more countries. 